\title{
Conceptions of homeopathy teaching in the faculties of pharmacy in the State of Rio de Janeiro
}

\author{
Giovania Firmino de Almeida, Carla Holandino \\ Federal University of Rio de Janeiro - RJ - Brazil
}

\begin{abstract}
Introduction: Homeopathy is a pharmaceutical and medical specialty practiced in Brazil since 1840 and known by the Federal Council of Medicine since 1980. The homeopathic pharmacy is a recognized part of the pharmaceutical profession regulated and supervised by the Federal Council of Pharmacy (CFF) and the Regional Councils of Pharmacy throughout Brazil (CFF 319/97 and CFF 440/05). Despite the existence of a Federal Law (number 1552, published in 1952) which implemented the teaching of "Notions of Homeopathic Pharmaceutical Techniques" in all colleges of pharmacy, these lectures are still not present in the majority of Brazilian Pharmacy curricula. This reluctance in the implementation of the teaching of homeopathy consists in an obstacle to the formation of new pharmaceutical homeopaths in Rio de Janeiro.
\end{abstract}

Aim: To evaluate how the teaching of homeopathy is being taught in undergraduate courses in pharmacy in Rio de Janeiro and register through a specific questionnaire, the students' interest, as well as the availability of internships in the field of homeopathy.

Methodology: The survey was started in May 2011 with a sample of ten pharmacy colleges in the state of Rio de Janeiro (UNIG, UNIGRANRIO, UNIABEU, UNIPLI, Universo Niterói, Universo São Gonçalo, UFRJ, UNISUAM, Estácio de Sá and UFF). A specific previously developed questionnaire was applied to undergraduate students to register their interest and availability for internships in the field of homeopathy. Moreover, the students were interviewed for relevant information about their interests in the area of homeopathy.

Results: Preliminary results showed that $57 \%$ of the respondents presented interest so far in qualifying in homeopathy pharmacy, $32 \%$ of them did not show any interest in the area and $11 \%$ reported not having a definite position. Regarding working with homeopathy, 51\% expressed interest in working in this area, 36\% showed no interest and 13\% were indecisive. As far as conducting a refresher course in homeopathy, 57\% showed interest, $35 \%$ showed no interest and $8 \%$ expressed no definite opinion. The traineeship of at least 240 hours, required by the Federal Council of Pharmacy to all pharmacists who wish to assume responsibility for technical laboratory or industrial homeopathic pharmacy, has not been offered by the majority of Pharmacy Faculties, considering that $89 \%$ of the respondents have not done this traineeship. Data collection will be finished by the second half of June.

Conclusion: The spread of homeopathy should be done from the beginning of the undergraduate course in pharmacy to evoke the interest in the discipline, especially in colleges where it is not compulsory. Most of interviewed students were not informed about the legal obligation of the training in the laboratory or pharmacy of homeopathy. Almost all colleges used in this study do not provide the internship for the students who show an interest in homeopathy. This scenario draws our attention to the necessity of new projects that enable a comprehensive and systematic teaching of homeopathy, providing new possibilities for homeopathic professional activities. 
Acknowledgments: post-graduation course in pharmaceutical compounding at the Pharmacy Faculty at UFRJ.

\section{Concepções de ensino da homeopatia nas faculdades de farmácia do Estado do Rio de Janeiro}

\section{RESUMO}

Introdução: A homeopatia é uma especialidade médica e farmacêutica praticada no Brasil desde 1840 e reconhecida pelo Conselho Federal de Medicina desde 1980. A farmácia homeopática é uma parte reconhecida da profissão farmacêutica regulada e supervisionada pelo Conselho Federal de Farmácia (CFF) e os conselhos regionais de farmácia em todo o Brasil (CFF 319/97 e CFF 440/05). Apesar da existência de uma Lei Federal (número 1552, publicada em 1952), que implementou o ensino de "Noções de Farmacotécnica Homeopática" em todas as faculdades de farmácia, esta disciplina ainda não está presente na maioria dos currículos de Farmácia do Brasil. Esta relutância na implementação do ensino da homeopatia consiste em um obstáculo para a formação de novos farmacêuticos homeopatas no Rio de Janeiro.

Objetivo: Mostrar como o ensino da homeopatia está sendo ministrado em cursos de graduação em farmácia no Rio de Janeiro e registrar através de um questionário específico, o interesse dos alunos, bem como a disponibilidade de estágios na área de homeopatia.

Metodologia: A pesquisa foi iniciada em maio de 2011, com uma amostra de dez faculdades de farmácia no estado do Rio de Janeiro (UNIG, UNIGRANRIO, UNIABEU, UNIPLI, UNIVERSO Niterói, UNIVERSO São Gonçalo, UFRJ, UNISUAM, ESTÁCIO DE SÁ e UFF). Um questionário específico desenvolvido anteriormente foi aplicado a alunos de graduação para registrar seu interesse e disponibilidade para estágios na área de homeopatia. Além disso, os alunos foram entrevistados para obter informações relevantes sobre os seus interesses na área da homeopatia.

Resultados: Os resultados preliminares mostraram que 57\% dos entrevistados apresentaram até agora o interesse na qualificação em farmácia homeopática, 32\% deles não mostrou qualquer interesse na área e 11\% relataram não ter uma posição definitiva. Ao trabalhar com a homeopatia, 51\% manifestaram interesse em trabalhar nesta área, 36\% não mostrou nenhum interesse e 13\% estavam indecisos. No que diz respeito à realização de um curso de reciclagem em homeopatia, 57\% mostraram interesse, $35 \%$ não mostraram interesse e 8\% não expressou nenhuma opinião definitiva. O estágio profissional de pelo menos 240 horas, exigido pelo Conselho Federal de Farmácia a todos os farmacêuticos que desejam assumir a responsabilidade técnica em farmácia ou laboratório industrial homeopáticos não vem sendo viabilizado pela maioria das Faculdades de Farmácia, considerando que 89\% dos entrevistados não realizaram até o momento este estágio curricular obrigatório. A coleta de dados deverá estar concluída até a segunda metade de junho.

Conclusão: A divulgação da homeopatia deve ser feita desde o início do curso de graduação em farmácia para evocar o interesse na disciplina, especialmente em escolas onde não é obrigatório. A maioria dos alunos entrevistados não foi informada sobre a obrigação legal do treinamento no laboratório de farmácia de homeopatia. Quase todas as faculdades utilizadas neste estudo não oferecem o estágio para os alunos que demonstram interesse em homeopatia. Este cenário, chama a nossa atenção para a necessidade de novos 
projetos que permitam um ensino abrangente e sistemático da homeopatia, oferecendo novas possibilidades para as atividades profissionais.

Agradecimentos: pós-graduação em composição farmacêutica na Faculdade de Farmácia da UFRJ.

\section{(cc) EY-NC-ND Licensed to GIRI}

Support: authors declare that this study received no funding

Conflict of interest: authors declare there is no conflict of interest

Correspondence author: Giovania Firmino de Almeida, giovania.aguiar@hotmail.com

How to cite this article: de Almeida GF, Holandino C. Conceptions of homeopathy teaching in the faculties of pharmacy in the State of Rio de Janeiro. Int J High Dilution Res [online]. 2011 [cited YYYY Month dd]; 10(36): 283-285 Proceedings of the XXV GIRI Symposium and VIII CBFH; 2011 Sep 04-07; Foz do Iguaçu (Brazil). GIRI and ABFH; 2011; Available from: http://www.feg.unesp.br/ ojs/index.php/ijhdr/article/view/476/486 